\title{
Comparison of Flipped classroom to traditional classroom lecture in Pharmacology among second year Dental Students
}

\section{Dr. Vibha Rani}

\author{
Associate Professor, Department of Pharmacology, Malla Reddy Medical College for Women, Suraram, \\ Hyderabad, India-500055
}

Corresponding author: Dr. Vibha Rani, Flat 408, Udaya Balaji residency, 1-1-17 A/B, Opp. Sudarshan theatre, Jawahar nagar, RTC X road, Hyderabad 500020

vibhabhat1984@gmail.com. 9246171731

DOI:10.47799/pimr.0901.07

Date of receiving: 24/12/2020

Date of Peer review: 15/01/2021

Date of acceptance: 6/02/2021

\section{ABSTRACT:}

Background: Flipped classroom is a teaching method where the students are involved in pre class preparations like watching related videos of lectures, reading relevant books and class time is utilized for clarifying doubts, discussion, class activity and problem solving Objectives: To compare traditional classroom lecture with Flipped classroom and to study the effectiveness and acceptability of the Flipped classroom approach in teaching Pharmacology. Methods: Second year dental students were divided into two groups-A and B of 37 each. Group A students, were given videos and voice over power point through Google group and What's app group on Antiepileptic drugs and after two weeks they were exposed to Flipped class using think pair and share class activity while group B students were given traditional lecture class on antiepileptic drugs. Both groups knowledge was compared using a post test questionnaire and group A students perception on flipped class was assessed using a three point Likert's questionnaire. Mean score between the two groups was compared using Man Whitney $U$ test and $p<0.005$ was considered as statistically significant. Results: $86 \%$ students preferred flipped class over conventional class and $95 \%$ liked think pair and share activity as it guided them in deeper understanding of the subject. Mean score was better among students involved in flipped class when compared to lecture class. Conclusion: Dental students had a good learning experience with the Flipped classroom method as it allowed them to learn at their pace and also guided them to apply learned information accurately.

Keywords: flipped class, lecture class, pharmacology, think pair share

\section{INTRODUCTION :}

Dental education has undergone drastic changes in the recent years and the main ideology of curriculum reformers is to promote active learning among the students and Flipped classroom is one such approach. ${ }^{(1)}$ Flipped classroom or inverted classrooms is a innovative active teaching learning method in which students gain first exposure to study resource materials before the class like reading textbooks or watching lecture videos and then the class room time is utilized in problem-solving exercises, case discussions, clearing doubts, where active learning takes place in the presence of teacher who carries the role of facilitator. ${ }^{(2)}$ It has long been proved the various advantages of active learning like improving communication skills, creating positive learning environment, developing better understanding between peers and students, developing critical thinking, improving retention ${ }^{(3)}$, flexible and better use of technology. ${ }^{(4)}$ The traditional lecture method of teaching has various flaws like it makes students passive learners, minimum interaction between teachers and students and also difficult to keep attention span of students throughout the class. ${ }^{(5)}$ In Flipped class room, the lower cognitive domains like applying, remembering and understanding are acquired by the students outside the classroom and the actual teacherstudent interaction time is utilized to train the students to apply the learnt principles which allows them to incorporate higher order thinking skills like creating, evaluating and analyzing. ${ }^{(6)}$ So a Flipped classroom is a setting where "which is traditionally done in class is now done at home, and that which is traditionally done as homework is now completed in class" as described by Bergmann and Sams (2012). ${ }^{(7)}$ In a study conducted at Neethravathi et al.(8) Flipped classroom approached improved the undergraduate students 
performance and in another study conducted by Sajid et al ${ }^{(9)}$ proved that this teaching method improved students retention. Other than medical field its success has also been highlighted in nursing field as shown in a systemic review done by V. Betihavas et al. ${ }^{(10)}$ which showed Flipped classroom method has shown to improve academic performance among the nurses and also a study done by Gubbiyappa et al. ${ }^{(11)}$ among pharmacy students showed this method improved students cognitive functions. It has also been proved that the Flipped classroom model was among the factors that had positive effects on students' self-directed learning readiness and students satisfaction. ${ }^{(12),(13)}$ In this study the active learning strategy that was adopted for students in Flipped class room was Think pair and share approach. This collaborative technique was first introduced in 1981 by Frank Lyman and it has shown to promotes active participation among students, encourages independent thinking and improves their communication skills ${ }^{(14)}$ and previous studies ${ }^{(15)}$ have shown that to improve students learning motivation and achievement.

Although there are several studies highlighting the effectiveness of Flipped class room, efficacy of this teaching method in the subject of Pharmacology among dental students are lacking. Hence, this study was planned to assess the effectiveness of flipped classroom as a teaching-learning tool using think pair share method as an active learning method among second year dental students.

\section{Materials and methods:}

This study was conducted among 74 second year dental students of Malla Reddy Dental College for Women, Hyderabad who were divided into two groups-Group A, B of 37 each. As it is a Womens dental college, all the participants in the study were females also oral consent was taken from participants and the purpose of conducting the study was explained to the students before conducting the study. Permission of Institutional Ethics Committee was taken before conducting the study. The topic selected for Flipped class room was Antiepileptic drugs. For Group A students, two weeks before the scheduled class activity, voice over power point and two videos on Antiepileptic drugs was sent through Google group and also via What's app group. Throughout these two weeks, all the group A students were guided and motivated by the facilitator via What's app group to go through the power points, videos and also read relevant standard text books. After two weeks Group A students were exposed to Think-pair-share on the topic Antiepileptics for 45 mins as a part of class activity. In the first phase of this activity, 11 questions were projected through power point and the students were instructed individually to find out the answers by referring to books and write down the answers. In the second phase of the class activity, students were paired up with others and were asked to pick the best answer for the given questions by discussing with their partner. In the final phase of the think-pair-share activity, the students were rejoined with the larger group and were asked to share their responses with the class and any doubts regarding the topic was cleared. 15 minutes was allotted for each of the Think-pair-share activity, so the total time required to complete this activity was 45 mins. After the end of this activity, students experience and perception regarding Flipped classroom was collected in the form of questionnaire (11) comprising of fourteen 3 point Likerts questions. Group B students were given a lecture class on Antiepileptics for 45 mins and a post test questionnaire consisting of 20 Multiple Choice Questions (MCQs) was administered to both A and B group students to assess their knowledge. The level of knowledge among the students was divided into 3 categories: poor (1-7), average (8-13) and good (14-20). Mean score between the two groups was compared using Man Whitney $U$ test and $p<0.005$ was considered as statistically significant.

\section{Results:}

This study was conducted to study the effectiveness and acceptability of the Flipped classroom approach in teaching Pharmacology and also to compare it with traditional classroom lecture among 74 female second year dental students. The mean age of the female students in the study was 18.3 years. The student's perception on Flipped class room is shown in Table 1. Figure1shows mean score comparison between flipped classroom (11.1) and lecture classroom (6.9) and Figure 2 shows score frequencies of lecture class and Flipped class room. Student's level of knowledge in both groups is shown in Figure 3. 97\% of Flipped class room students agreed that the pre-reading materials like power point presentation, videos helped them to solve the MCQs easily as shown in Figure 4. As seen in figure 5, $86 \%$ students preferred Flipped class over conventional lecture class.

Table 1: Dental students perception on flipped class room

\begin{tabular}{|c|l|c|c|c|}
\hline S.No. & \multicolumn{1}{|c|}{ Item } & $\begin{array}{c}\text { Agree } \\
\text { (\%) }\end{array}$ & $\begin{array}{c}\text { Neutral } \\
\text { (\%) }\end{array}$ & $\begin{array}{c}\text { Disagree } \\
\text { (\%) }\end{array}$ \\
\hline 1 & $\begin{array}{l}\text { Pre-reading materials which were provided helped me to solve the MCQs } \\
\text { easily }\end{array}$ & 97 & - & 3 \\
\hline 2 & $\begin{array}{l}\text { Pre-reading materials provided were relevant for the flipped class room } \\
\text { activity }\end{array}$ & 97 & 3 & - \\
\hline 3 & I prefer flipped class over conventional teaching & 86 & 11 & 3 \\
\hline
\end{tabular}




\begin{tabular}{|c|l|c|c|c|}
\hline 4 & $\begin{array}{l}\text { Adequate time was provided to spend on pre reading materials (voice over } \\
\text { power point, you tube videos) }\end{array}$ & 97 & 3 & - \\
\hline 5 & I like watching lessons in the form of videos & 73 & 24 & 3 \\
\hline 6 & $\begin{array}{l}\text { The lecturer was able to engage during the flipped class activity and she } \\
\text { was able to provide clarifications on difficult topic }\end{array}$ & 100 & - & - \\
\hline 7 & $\begin{array}{l}\text { The activities during the flipped classroom session increased my } \\
\text { understanding on the topic }\end{array}$ & 95 & 4 & 1 \\
\hline 8 & $\begin{array}{l}\text { I know I can learn many more things when my lecturer using flipped } \\
\text { method }\end{array}$ & 94 & 3 & 3 \\
\hline 9 & $\begin{array}{l}\text { The flipped class room method has improved my understanding and has } \\
\text { given me more time to study the topic }\end{array}$ & 89 & 11 & - \\
\hline 10 & Flipped classroom has reduced my understanding & 68 & 27 & \\
\hline 11 & Flipped class gives greater opportunity to communicate with others & 95 & 5 & - \\
\hline 12 & In flipped class room the entire class was moving at the same pace & 76 & 22 & 3 \\
\hline 13 & In future more lectures should be conducted in flipped class room mode & 92 & 8 & - \\
\hline 14 & I would like to recommend flipped class to my friends & 92 & 8 & - \\
\hline
\end{tabular}

Fig.1: Mean score comparison between lecture class and flipped class room

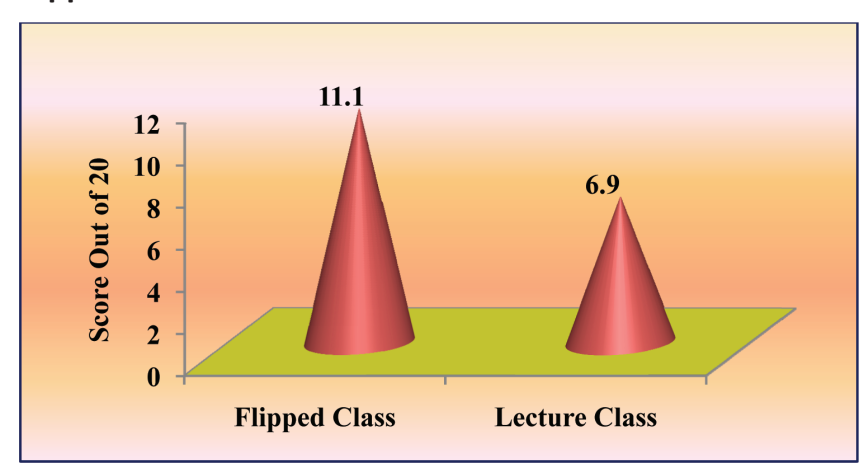

Fig. 2: Score frequencies of lecture class and flipped class room

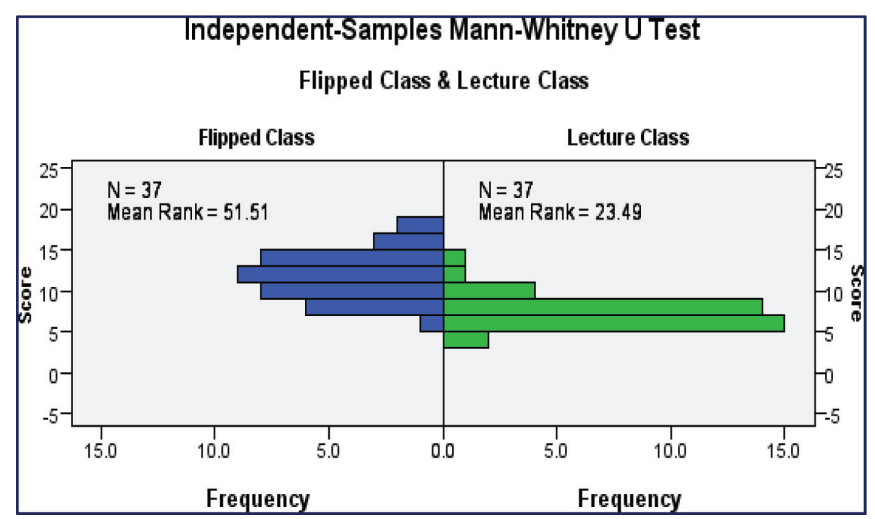

Fig.3: Comparison of knowledge between lecture class and flipped class room

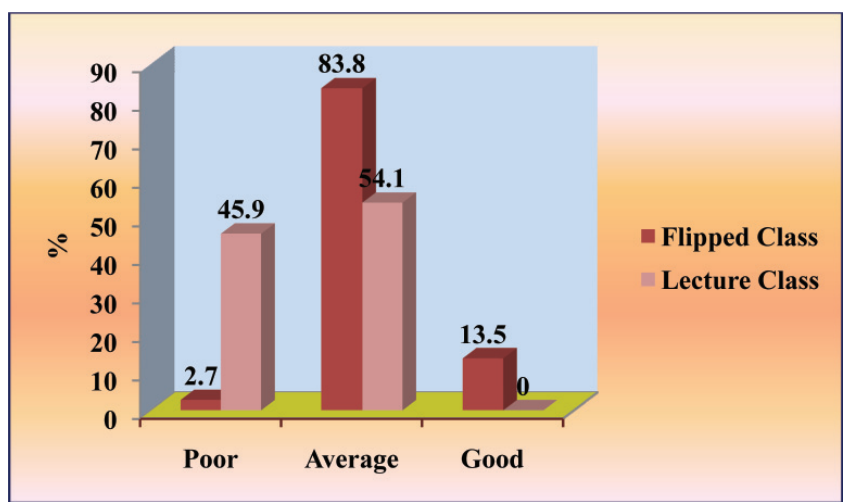

Fig. 4: Pre-reading materials which were provided helped to solve the MCQs easily

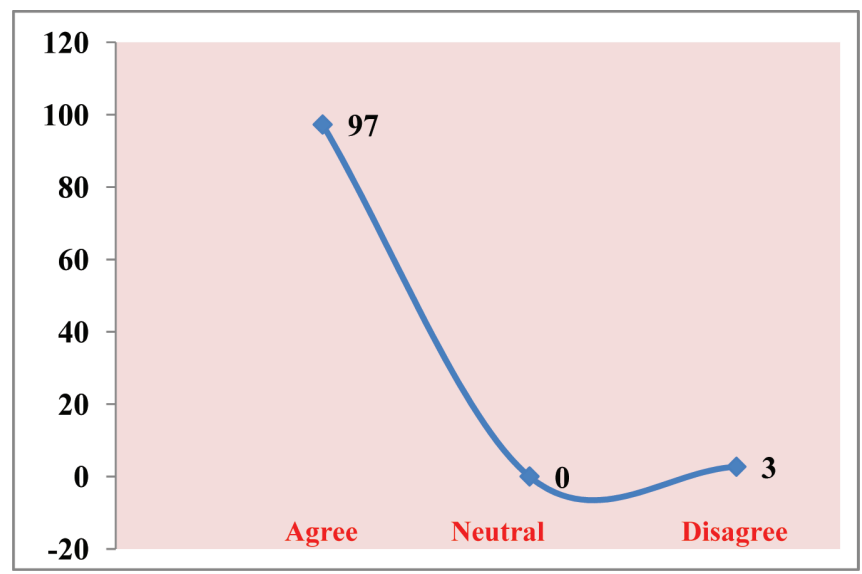


Fig. 5: I prefer flipped class over conventional teaching

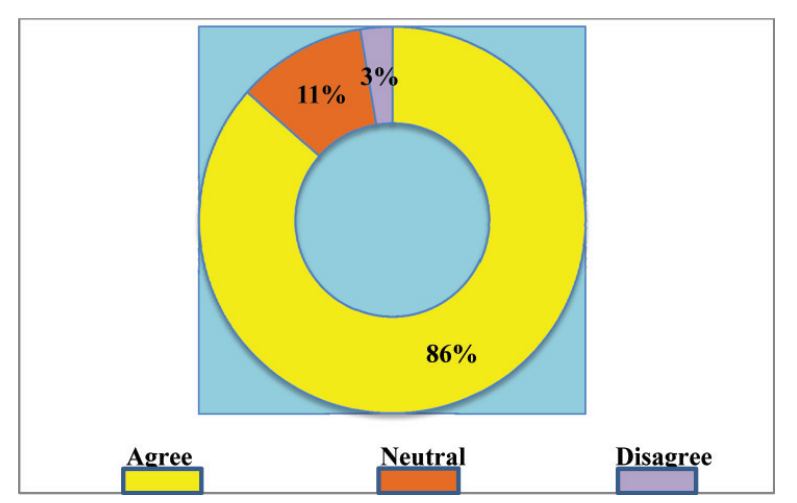

Discussion:

This study was conducted among undergraduate dental students in the subject of Pharmacology employing the traditional lecture class and Flipped classroom models of teaching. Dental students have to face everyday changes in this complex world where there constant changes in technology, education, medical as well as social field. So the students should prepare themselves for all the challenges which they might face in their future. The present generation of students have a very different mindset towards learning and they are all updated and familiar with the technology tools. Use of technology tools with innovative teaching are being encouraged as it helps students to learn at their own pace and amongst the technology-supported education, Flipped classroom stands out.

In the study $92 \%$ wanted to have more classes in the form of Flipped class than traditional class the result of which is less when compared to a similar study where it was higher.(11), (17) The result implies that students have greater acceptability towards this method, more in ease towards use of technology tools and also these youngsters are quite confident with these newer learning methods. Also here $95 \%$ felt that this method provided them greater opportunity in communicating with others the result of this is higher when compared to another study ${ }^{(18)}$ where it was $76 \%$. The student's needs to have good communication skills which helps them to build a stronger doctor patient relationship and these type of blended learning methods are very effective in improving students communication skills. $89 \%$ students liked this method because it gives flexibility which allows them to learn at their own pace the result is less when compared to another study ${ }^{(19)}$ where it was $97.4 \%$. Flexible learning encourages students to be more accountable for their own learning and helps them to coordinate their schedule. ${ }^{(20)}$

$74 \%$ of the students liked the videos which they viewed as pre class reading materials. Videos are powerful tools for students which allows them pace it at their time, allows simplifying complex subjects and also give more information in limited time. ${ }^{(21)}$ Also $95 \%$ of Flipped class students agreed that the think pair and share strategy which was used for class activity helped them in deeper understanding of the topic and likewise, this activity had a positive impact on students in other similar studies. ${ }^{(22),(23)}$

In this study, the mean score is better among students involved in Flipped class in comparison to lecture class. Similar comparison studies also done among undergraduate students showed better acceptability in Flipped classroom along with improvement in academic performance. ${ }^{(24),(25),(26)}$. In the contrary, similar study ${ }^{27}$ showed no statistically significant differences between the scores of conventional and Flipped class group. Certain limitations of this study was, this was done taking a single topic in Pharmacology and the generalizability of this study is limited as it was conducted only in one discipline and at one center.

In keeping up with pace of students and their mindset, there is need to modernize and technologize the dental curriculum, so Flipped classroom approach could be a better option over the traditional lecture-based classroom. In the recent years, dental education has become more advanced and challenging and the use of technology tools along with the use of class activities will be helpful in keeping the interest and enthusiasm of the students as they are well proficient in using the technology. Also this method provides students vast information by engaging students in active learning process and incorporates deep critical thinking skills. ${ }^{28}$

In this study Flipped classroom model was positively received and appreciated by majority of dental students as there was independent learning and encouraged students to pace themselves. This method needs to be tailor made into dental curriculum, keeping in mind students learning preferences so that it becomes more acceptable and feasible to both students and faculty. Students will have enriching learning experience if the Flipped model can be incorporated as a blended teaching method. Therefore this method can be incorporated as a part of regular teaching in undergraduate dental curriculum.

Acknowledgment: I would like to thank 2018 dental students for their active participation, cooperation and enthusiasm which helped me in conducting this study

\section{REFERENCES}

1. L Maximilian Buja. Medical education today: all that glitters is not gold. BMC Medical Education 2019; 19(1):110.

2. Arnold-Garza. The flipped classroom teaching model and its use for information literacy instruction. Communications in Information Literacy 2014; 8(1):7-22. 
3. Shaaruddin J, Mohamad M. Identifying the Effectiveness of Active Learning Strategies and Benefits in Curriculum and Pedagogy Course for Undergraduate TESL Students. Creative Education 2017; 8(14): 2312-24.

4. Sudha Srinivasan, Harish Kumar. Flipped Classroom Model-A Response to the Emerging Trends in the Teaching Learning Landscape. International Journal of Recent Technology and Engineering 2019; 8(3):297-304.

5. Gurpreet Kaur. Study and Analysis of Lecture Model of Teaching. International Journal of Educational Planning \& Administration 2011; 1(1): 9-13.

6. Roopashree, Medha A Joshi, Gopikumar, Jaisri Goturu. Effectiveness of Flipped Class Room as a Teaching Tool: A Pilot Study. NJIRM 2017; 8(4):78-84.

7. Prashanti Eachempati, Kiran Kumar KS, Abdul Rashid Hj Ismail. The flipped classroom in dental education Learning beyond the four walls of the classroom. Med Ed Publish 2018; 7(1):42.

8. Angadi NB, Kavi A, Shetty K, Hashilkar NK. Effectiveness of flipped classroom as a teaching-learning method among undergraduate medical students -An interventional study. J Edu Health Promot 2019; 8:211.

9. Muhammad R. Sajid, Abrar F. Laheji, Fayha Abothenain, Yezan Salam, Dina Al Jayar, Akef Obeidat. Can blended learning and the flipped classroom improve student learning and satisfaction in Saudi Arabia? Int J Med Educ 2016; 7:281-85.

10. Vasiliki Betihavas, Heather Bridgman, Rachel Kornhaber, Merylin Cross. The Evidence for 'Flipping Out': A Systematic Review of the Flipped Classroom in Nursing Education. Nurse Educ Today 2016; 38:15-21.

11. Gubbiyappa KS, Barua A, Das B, Vasudeva Murthy CR, Baloch HZ. Effectiveness of flipped classroom with Poll Everywhere as a teaching-learning method for pharmacy students. Indian J Pharmacol 2016; 48 (Suppl 1):S41-S46.

12. Su-Fen Cheng, Jane Lee-Hsieh, Chu-Yu Huang. Flipping the classroom to improve self-directed learning for RN to BSN students in Taiwan. J Nurs Care 2015; 4:4.

13. Ya-Qian Liua, Yu-Feng Lia, Meng-Jie Leia, Peng-Xi Liub, Julie Theobaldb, Li-Na Menga, Ting-Ting Liua. Effectiveness of the flipped classroom on the development of self-directed learning in nursing education: a meta-analysis. Front Nurs 2018; 5(4): 317-30.

14. Lia Yulianingsih. The use of think pair and share technique in teaching reading to the seventh grade of senior high school. Academic Journal perspective: Language, Education and Literature 2017; 5(2): 99-108.

15. Abdurrahman Hi Usman. Using the Think-Pair-Share Strategy to Improve Students Speaking Ability at Stain Ternat. Journal of Education and Practice 2015; 6(10):3745.

16. Hetika, Ida Farida, Yeni Priatna Sari. Think Pair Share (TPS) as method to improve students learning motivation and learning achievement. Dinamika Pendidikan 2017; 12(2):125-13.

17. Raveendranath Veeramani, Venkatesh S. Madhugiri, Parkash Chand. Perception of MBBS student to "flipped class room" approach in neuroanatomy module. Anat Cell Biol 2015; 48 (2):138-143.

18. Sunita Sreegiri, B Devi Madhavi, Lakshmi Kumari."Student's Perception of Flipped Classroom Teaching Method in Andhra Medical College, Visakhapatnam." IOSR Journal of Dental and Medical Sciences 2018; 17(2):6-9.

19. Roopashree, Medha J, Gopi k, Jaisri G. Effectiveness of Flipped Class Room as A Teaching Tool: A Pilot Study. Natl J Integr Res Med 2017; 8(4):78-84.

20. Mousazadeh Somayeh, Maryam Dehghani, Farzaneh Mozaffari, Seideh Madineh Ghasemnegad, Hamideh Hakimi, Bagherian Samaneh. Int J Med Res Health Sci 2016; 5(2): 86-91

21. Larry Hurtubise, Bryan Martin, John Mahan. To Play or Not To Play: Leveraging Video in Medical Education. J Grad Med Educ 2013; 5(1):13-18.

22. Sumekto D. R. Investigating the influence of think-pairshare approach toward students reading achievement. Lingua Cultura 2018; 12(2): 195-202.

23. Cheryl Lee, Hui-Chuan Li, Masitah Shahrill. Utilising the Think-Pair-Share Technique in the Learning of Probability. IJEME 2018; 2 (1): 49-64.

24. Deepak Nallaswamy V, Subha M, Asha R. Conventional lectures vs the flipped classroom: Comparison of teaching models in undergraduate curriculum. Int. J. Res. Pharm. Sci 2018; 10(1):572-76.

25. Fen Tanga, Chuan Chen, Yi Zhu, Chengguo Zuoa, Yimin Zhonga, Nan Wanga, Lijun Zhou, Yuxian Zoua, Dan Lianga. Comparison between flipped classroom and lecture-based classroom in ophthalmology clerkship. Med Educ Online 2017; 22(1):1395679 
26. Unal Z, Unal A. Comparison of Student Performance, Student Perception, and Teacher Satisfaction with Traditional versus Flipped Classroom Models. International Journal of Instruction 2017; 10(4): 145-64.

27. Cabi E. The impact of the Flipped classroom model on students academic Achievement. Int Rev Res Open and Distrib Learn 2018;19: 202-21.

28. Kuldeep Singh, Rajiv Mahajan, Piyush Gupta, Tejinder Singh. Flipped Classroom: A Concept for Engaging Medical Students in Learning. Indian Pediatr 2018; 55: 507-12.

How to cite this article : Vibharani. Comparison of Flipped Classroom to traditional classroom lecture in pharmacology among second year Dental Students. Perspectives in Medical Research 2021; 9 (1):31-36

DOI:10.47799/pimr.0901.06

Sources of Support: Nil, Conflict of interest: None declared 